\title{
Erratum to: Migration and validation of non-formal and informal learning in Europe: Inclusion, exclusion or polarisation in the recognition of skills?
}

\author{
Manuel Souto-Otero ${ }^{1} \cdot$ Ernesto Villalba-Garcia $^{2}$
}

Published online: 25 November 2015

(C) Springer Science+Business Media Dordrecht and UNESCO Institute for Lifelong Learning 2015

\section{Erratum to: Int Rev Educ DOI 10.1007/s11159-015-9516-7}

The authors missed to include a disclaimer in the Original Published article which was important. The same is published in this Erratum.

The current article does not constitute policy and might not necessarily present the views of Cedefop.

The online version of the original article can be found under doi:10.1007/s11159-015-9516-7.

$\triangle$ Manuel Souto-Otero

manuelsoutootero@gmail.com

Ernesto Villalba-Garcia

ernesto.villalba-garcia@cedefop.europa.eu

1 School of Social Sciences, Cardiff University, Cardiff, UK

2 European Centre for the Development of Vocational Training (Cedefop), Finikas, Thessaloniki (Pylea), Greece 